\title{
Conjunctions of the Literary and the Philosophical in Twentieth- and Twenty-First-Century American Writing
}

Richard Anker and Stéphane Vanderhaeghe

\section{(2) OpenEdition}

Electronic version

URL: https://journals.openedition.org/transatlantica/15488

DOI: $10.4000 /$ transatlantica. 15488

ISSN: 1765-2766

Publisher

Association française d'Etudes Américaines (AFEA)

Electronic reference

Richard Anker and Stéphane Vanderhaeghe, "Conjunctions of the Literary and the Philosophical in Twentieth- and Twenty-First-Century American Writing", Transatlantica [Online], 1 | 2020, Online since 01 December 2020, connection on 01 February 2023. URL: http://journals.openedition.org/ transatlantica/15488; DOI: https://doi.org/10.4000/transatlantica.15488

This text was automatically generated on 1 February 2023

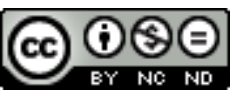

Creative Commons - Attribution-NonCommercial-NoDerivatives 4.0 International - CC BY-NC-ND 4.0 https://creativecommons.org/licenses/by-nc-nd/4.0/ 


\title{
Conjunctions of the Literary and the Philosophical in Twentieth- and Twenty-First-Century American Writing
}

\author{
Richard Anker and Stéphane Vanderhaeghe
}

1 Although in the history of the West the relation between the literary and the philosophical has often been conceived in terms of a rivalry, perhaps with one field or regime of discourse attempting to annex or tame the other, what the articles collected in this volume devoted to twentieth and twenty-first century American writing reveal is a rather striking display of conjunctions presenting a less antagonistic image of their relation. This may confirm Stanley Cavell's famous assertion that America expresses itself philosophically in the "metaphysical riot" of its greatest literature (33). It is doubtful, however, that Cavell had twentieth-century literature in mind when, in the early 1970s, he delivered his lectures on Walden. The articles collected in this volume are meant to address the question of the relationship between literature and the philosophical at a time when the "metaphysical" itself has been challenged, both from within the institutional limits of philosophy and from without. Indeed, this is one, if not the major, distinction to be made when considering entanglements of the literary and the philosophical in our time in comparison with that of writers like Hawthorne and Melville: the fact that "demarcating the disciplines" (Weber) since what is commonly regarded as the "end of metaphysics" has become a problematic endeavor at best, one of the functions of metaphysics (whatever its own turbulences) being precisely to provide models of structuration, to impose regimes of signification, and to forestall the retrogression toward rhetoric and discursive play that has erupted in diverse forms of modern writing.

2 If, furthermore, one considers the "end" of metaphysics to have been the installation, apparently definitive by the dawn of the twentieth century, of a techno-scientific determination of the will to power, perhaps nowhere more evident than in the United 
States, then this question of the relationship between the literary and the philosophical in recent American writing becomes even less tenable as a reliable heuristic opposition. Metaphysics has not ceased coming down to earth, penetrating (and extending) our minds and bodies, our media and natural environments, in ways that even the nineteenth century could not have imagined. The philosophical, despite its own selfregulating obsessions, is not always where one anticipates it is, while the literary, for its part, extends its immemorial deviation from logocentric self-awareness into the modern age of new media ecologies. All this is to say that if the terms "literary" and "philosophical" have been retained in coordinating this volume-and prior, in organizing the 2017 conference that prompted $i^{1}{ }^{1}$ it has not been without some degree of wistful deliberation or irony. These terms, and the discursive regimes they represent, doubtless still matter, and will continue to do so for some time. The articles collected here vary in the attitudes adopted with respect to the demarcation in question, and summon their critical outlooks from different vantage points in the historical evolution of the "conjoining" disciplines of the literary and the philosophical. But the overall tendency among them reflects the on-going destabilization among the disciplines and invites the reader to look beyond static or merely oppositional modes of considering the conjunctions invoked here. It invites one to read beyond, in other words, the metaphysical patterns of thinking which, up to the period under scrutiny and spurred by ideological modes of thought and behavior that refuse to recede, have traditionally dominated relations between the literary and the philosophical.

3 Thinking beyond the sterile ideological reactions to the destabilization in question (which exceeds the confines of academic culture and is echoed throughout globalized, or Americanized, cultural and aesthetic mediums) calls for an understanding of the "literary" and the "philosophical" beyond the waning prestige still imparted to these terms by the humanities. Behind the literary and the philosophical, and implicit in the variety of conjunctions addressed in this volume, lies not only the "ancient enmity" that Plato identified between muthos and logos, but an unruly consort of other, no less incorrigibly intractable, conceptual pairs: mimesis and praxis, imagination and thought, tropes and truth, figure and concept, author and subject, representation and presentation, to name a few. What we persist in calling the "literary" and the "philosophical" are thus metonymies for a sprawling array of discursive oppositions inherent to Western art, thought and cultural practices. The interval between these terms has not been tamed but distended itself rather and proliferated with the twentieth and twenty-first centuries' intensification of medium-oriented cultural and aesthetic awareness. It is likely that this interval and the conjunctions it supposes, however formulated, will accompany us far beyond the demise of institutions (academic to begin with) whose origins are inscribed within the humanist tradition of the literary-philosophical.

4 Far from suggesting, then, some kind of conflation of the literary and the philosophical, the conjunctions studied in this collection may perhaps best be understood as loci where the limits between these traditionally isolated domains of thought and language intertwine, entangle, often producing tensions which echo, across discursive reconfigurations, the very dissension that Plato alerted us to (or, rusefully, established). If rivalry, however, seems not quite the appropriate term to define even the more contentiously established conjunctions of the literary and the philosophical observed in this collection, perhaps it is simply because many American writers of the twentieth and twenty-first centuries have lived in a world of techno-scientific 
developments and information systems far too complex for any single mind, however lofty its philosophical pretensions, to know or even experience directly. What comes in the place of rivalry, then, as an implicitly heroic staging of binary identities-Socrates against the Tragedians, Hegel versus the Romantics, Nietzsche contra Wagner, or the Virgin and the Dynamo in Henry Adams's casting of the creative/productive agon-are more intimate and less territorialized forms of difference disseminated across a spectrum of writing practices.

5 The works of American poetry, fiction, and dance that are discussed here may thus be considered "supreme fictions" (Stevens) that invite us to consider the myriad ways in which writing from the modernists to our day obliges us to rethink the old antagonisms in new terms. Some papers (notably those dealing with the poetry of Stevens and Williams) tackle the philosophical as it comes down to us through the tradition in the works of major philosophers, from Plato to Badiou and Agamben, either showing how writers attempt to negotiate the trope-truth schism within their works or else borrowing from recent philosophical discourse the conceptual language necessary to elucidate a poetics less self-reflexively engaged with the philosophical. Some draw occasionally on the American past and the philosophically charged rhetoric of its religious heritage, while several of the papers dealing with the postmodern novel (Pynchon, DeLillo, McElroy) focus on the philosophical conditions of science and technology as they determine modern life in our increasingly rationalized and mediabased societies.

6 Our collection opens with a reflection on the modernist poem as a problematic, openended site where the object of the poem strives to meet up with the poem as object; this, as Aurore Clavier demonstrates, entails an opening up of the poem to the philosophical in the form of the essay, a non-genre of sorts that, posited on the margins of the literary, gestures toward a common ground between poetry and philosophy, in open defiance of Plato's demarcation of the disciplines and a rejection of the hierarchical relation between philosophical truth and poetical illusion. As such, the modernist poem, as encountered in the works of Williams, Stevens, or Moore, among others, tends to reflect upon itself from this "placeless place" analyzed by Giorgio Agamben, thus unfurling while staging its reluctance ever to begin or end. In the process the poetic discourse remains open-ended, lodged in an interval or in-between space that paradoxically undoes or undefines it.

7 Following Clavier's argument, Bart Eeckhout's article re-opens the case for Wallace Stevens's philosophical leanings but chooses to adopt a pragmatic approach by confronting two sorts of responses, different in kind, to the New England writer's poetry: first a poetic response as diversely propounded by poets grappling with Stevens's legacy, and, second, a philosophical response as found in essays by Alain Badiou and Philip Hare. What results from this attempt at sketching the possibility of a dialogue between the literary and the philosophical is a radical misunderstanding as soon as the relation of poetry to philosophy and of philosophy to poetry is not contextualized. What Stevens's work tends to show in the end is indeed the "deep play," throughout, of the metaphorical over the conceptual, which begs for a constant negotiation and recognition of what poetry is and does, as well as what specific terrain philosophy strives to map out.

8 In Adeline Chevrier-Bosseau's article, the dialogue between the literary and the philosophical is displaced or translated onto the scenic performances of choreographer 
Martha Graham. Focusing on Graham's Letter to the World, a ballet recounting Emily Dickinson's struggle with the limitations imposed upon her by her Puritan legacy, Chevrier-Bosseau shows how Graham's conception of dance is based on her understanding of Nietzsche's concept of Umwertung to question and revalue the place of the (female) body in relation to beauty, truth, and eventually an ideal construction of democracy inherited from Whitman's poetry. If dance, for Graham, is "a gesture towards the truth," the choreographer's graphic and ritualistic representations of the female body on stage serve as a revaluation of the Puritan heritage and tradition that greatly informed, according to Graham, American creativity. The literary and the philosophical, as translated on stage, thus ultimately enhance a celebration of the body's sacredness against the grain of generic divisions and partitions.

9 Nicholas Manning's take on the issue relates to realist fiction's apparent rejection of anything philosophical. As recalled by Manning, in contradistinction to postmodernist or, more generally, experimental fiction, realism fosters the celebration of direct, lived experience and eschews overly reflexive stances. However, by focusing on Richard Ford's The Sportswriter, Manning shows that this so-called anti-philosophical positioning, with Ford's narrator promoting a passive, non-reflexive, pragmatic acceptation of what happens in the present, already consists in a philosophical posture arguing against itself. Bascombe's verbosity eventually belies its philosophical underpinnings, which are defined by and showcased in the ironical reflexivity of the novel's discourse. In contrast to traditional works of realist fiction which tend to privilege a philosophy of socio-political or ethical engagement, and presuppose stable epistemologies seen as underwriting American values like self-autonomy, liberty and egalitarianism, The Sportswriter directly challenges myths of transparency and immediate experience, and finds philosophical affinities with post-structuralist questionings about language, selfhood and alterity.

10 Arkady Plotnitsky moves the issue toward science and the philosophy of science to question the uses to which Thomas Pynchon's novels put scientific concepts borrowed mostly from quantum theory. Following Joyce's Finnegans Wake, Pynchon's fiction experiments with multiple ontologies or "spaces of variation." According to Plotnitsky, Pynchon's dives into quantum theory aim to open up fiction onto speculative thought and provide access to a "real without realism" posited outside classic modes of representation. The persistence of mathematics and, more generally, of science throughout Pynchon's œuvre is thus seen as a "sinthome" of a "radical modernism" to be found both in literature and science, which turns Pynchon into a "radical modernist" working toward the delineation of a "real without realism," a concept introduced by Plotnitsky in previous theoretical works and which has certain affinities with Lacan's notion of the Real. Basing his reflections on a broad corpus of works from $V$ to Against the Day, and including primarily The Crying of Lot 49, Gravity's Rainbow, Vineland and Mason \& Dixon, Plotnitsky shows how Pynchon's compositional (as opposed to representational) strategies, which allegorize the powers of chance and the powers of probability, ultimately enable readers to relate to realities, or "experimental ontologies," richer than anything mathematics and quantum mechanics themselves have been able to handle.

11 As for him, Richard Anker places the work of contemporary writer Joseph McElroy within a pastoral tradition, a critical move that cannot be taken for granted in view of a work often regarded in its relation to science and technology. In doing so, McElroy is 
set apart from the paranoid or apocalyptic stance that is evident in many postmodern writers with respect to technology, like Gaddis and Pynchon. For Anker, McElroy's pastoral, anti-paranoid ethos derives from a revision of the art/nature, technè/phusis partition in favor of a holistic, yet discontinuous, conception of a "total ecology" that is irreducible to the kind of Manichean oppositions that determine Adams's vision of technological modernity. Anker argues that "McElroy's pastoral ethos originates not as a counter to our techno-scientific alienation and destruction of nature [...] but, more fundamentally, as a response to the ontological retreat of nature inherent to human being." Most extensively developed in the author's 1987 magnum opus Women and Men, the over-arching impulse defining McElroy's pastoralism would be the quest to relocate truth as "the unveiling of the world in its appearance, that is, in its irreducible figurality." Analogous to what the French philosopher Gérard Granel called the "mute philosophy" of art, defined as a quest to retrieve from the world the conditions of its appearance, this drive to unveil the dissimulating structure of being, to make the enigma of appearance appear, is what determines a haunted sense of the "difference between nature 'itself' and nature as an eidetic reality" in the main male protagonist of the novel, James Mayn, and an obsessive attachment to the ghostly maternal origin of his existence.

Andrea Pitozzi looks at Don DeLillo's post-millenial production and focuses on three of his later novels, The Body Artist, Point Omega, and Zero K, to examine their philosophical reconfiguration of, and reflection on, time as meditated upon by the diverse characters at the center of DeLillo's novels. Pitozzi notably studies the way in which what he calls narrative images find their way into the texts' storylines, thus suspending their narrative development, loosening the plots, and puncturing the texts' fabric. The suspensions that manifest themselves in DeLillo's work are one of the ways that the interval between the philosophical and the literary, truth and tropes, proves itself irreducible, much like the hauntedness just mentioned in McElroy's writing. The result is the creation of textual interstices in the Deleuzian sense of the word. For Pitozzi, this (non-)narrative strategy consists not so much in the description of diverse preexisting images (which might have been the case in DeLillo's earlier production), as in the attempt to forge true "time-images" susceptible to write time in an all too transitive way, giving rise to what Pitozzi refers to as DeLillo's chronography.

In her study of Percival Everett's The Water Cure and Virgil Russel by Percival Everett, Sylvie Bauer insists eventually on the very gesture in which writing consists and which she posits at the origin of thought's advent. Everett, she argues, opts for fragmentary forms that challenge, while undermining the conventions of the traditional novel, the possibility of ever getting at some coherent, interpretable meaning, since Everett's writing pits, one against the other, "the mastery of language and the indifference of the world to anything it contains." As explicitly staged in the very title of Virgil Russel by Percival Everett, Everett intermingles the literary and the philosophical, and treats language in such a way that writing verges on non-sense in the process-a strategy halfway between the literary and the philosophical that subtracts the texts from the fixity and rigidity of sense as obtained through interpretation. It is eventually such resistance to knowledge and meaning that open the texts up to the philosophical, in a material gesture that conjoins both discourses while erasing their generic differences.

As a postscript to this collection of essays, writer and scholar Ralph Berry takes his cue from Wittgenstein to reframe the initial question concerning the conjunction of 
twentieth and twenty-first century literature and the philosophical. It would seem, suggests Berry, that in order to assess this conjunction, one has to wonder first how to define, conceptually, both literature and philosophy. The question, in other words, is one that bears on our preliminary understanding of such concepts as "literature" or "philosophy." However, as expounded in Wittgenstein's Philosophical Investigations, it might well be the very task of philosophy to blur concepts, to question and challenge them out of conventional, formulaic definitions. If virtually no one would dispute any specific novel on the grounds that it is not a novel, they would be at great pains to define what the concept of novel is, falling instead on subjective notions of what a good novel is or should be. In the end, one always fails to conceptualize and convincingly explain what any aesthetic concept corresponds to, finding refuge instead in examples. A novel is always exemplary in that sense. It is perhaps to that extent, then, argues Berry, that the literary and the philosophical intermingle, since part of a novel's taskwhich could no doubt be extended to other literary genres or media-always already consists in interrogating what makes it a "novel." In the process, it questions its own inscription within a specific history marked by aesthetic revolutions or interruptions that challenge the permanence of our concepts "at all time." Focusing on Woolf's To the Lighthouse and its formal conceptualization of time and chronology, as well as its treatment of the fictional character, Berry eventually concludes that there is knowledge of our aesthetic concepts only in examples indeed.

Let these, then, be examples of the fruitful conjunctions that twentieth and twenty-first century American literature, from the modernist poem to the contemporary experimental novel, have been relentlessly seeking with the philosophical.

\section{BIBLIOGRAPHY}

Cavell, Stanley. The Senses of Walden. An Expanded Edition. San Francisco: North Point Press, 1981.

Weber, Samuel, ed. Demarcating the Disciplines. Philosophy, Literature, Art. Minneapolis: The University of Minnesota Press, 1986.

\section{NOTES}

1. The conference "American Literature and the Philosophical," organized by Richard Anker, Thomas Constantinesco, Mathieu Duplay, Cécile Roudeau and Stéphane Vanderhaeghe, was held March 23-25, 2017, at Université Paris-Diderot and Institut des Études Avancées. All of the articles published in this collection, except those of Anker and Chevrier-Bosseau, are based on papers initially delivered at that conference. Articles based on papers delivered at the same conference, but dealing with nineteenth-century American literature, have been edited by Thomas Constantinesco and Cécile Roudeau and published under the title "The House of Thought': Nineteenth Century American Literature and the Philosophical," in Textual Practice, vol. 33, issue 10, 2019. 


\section{AUTHORS}

\section{RICHARD ANKER}

Université Clermont Auvergne

\section{STÉPHANE VANDERHAEGHE}

Université Paris 8-Vincennes-Saint-Denis 